\title{
Relationship between peak and mean amplitudes of the stimulating output voltage for functional control of the knee by spinal cord patients and healthy volunteers
}

Eddy Krueger*, Eduardo Mendonça Scheeren, Guilherme Nunes Nogueira-Neto, Eduardo Borba Neves, Vera Lúcia da Silveira Nantes Button, Percy Nohama

\begin{abstract}
Introduction: Functional electrical stimulation (FES) may evoke movements in people with movement impairments due to neurological lesion. The mean value of electrical current or voltage during FES depends on the stimulatory profile parameters. To investigate the relationship between peak and mean amplitudes of the stimulator output voltage while causing a knee extension angle change from $90^{\circ}$ to $40^{\circ}$ to choose the best and safest profile to be applied in people who have suffered a spinal cord injury. Methods: Healthy $(N=10)$ volunteers and those with spinal cord injuries $(N=10)$ participated in this study. Each FES profile (P1, P2, P3 and P4) had 1-kHz pulses (100 $\mu$ s or $200 \mu$ s on and $900 \mu \mathrm{s}$ or $800 \mu$ s off) with burst frequencies of $50 \mathrm{~Hz}$ ( $3 \mathrm{~ms}$ on and $17 \mathrm{~ms}$ off) or $70 \mathrm{~Hz}$ ( $3 \mathrm{~ms}$ on and $11 \mathrm{~ms}$ off) and peak amplitudes set between 53-125 V for healthy volunteers and 68-198 Vfor volunteers with spinal cord injury. Results: The highest mean amplitude were obtained using a FES profile with active/total pulse period of 200 us/1000 us and burst frequency of $3 \mathrm{~ms} / 14 \mathrm{~ms}$. The best results of mean amplitude were observed using a FES profile duty cycle of $10 \%$ for pulses $(100 \mu \mathrm{s} / 1000 \mu \mathrm{s})$ and $15 \%$ for bursts $(3 \mathrm{~ms} / 20 \mathrm{~ms})$. Conclusion: The FES profile (100 $\mu \mathrm{s}-50 \mathrm{~Hz})$ seems to be the most suitable for both groups, inasmuch as it presents smaller mean amplitudes and peak amplitudes similar to other FES profiles.
\end{abstract}

Keywords Functional electrical stimulation (FES), Spinal cord injury, Stimulatory parameters, Stimulatory profiles. 


\section{Introduction}

Functional electrical stimulation (FES) is the application of electrical pulses to neural pathways (Kesar et al., 2010). This technique can be used to create functional movements artificially for people who have suffered spinal cord injuries (Kern et al., 2010a). However, FES efficiency may be impaired due to physiological alterations, such as muscular fatigue (Enoka and Duchateau, 2008; Yu and Chang, 2010) and/or motoneuron adaptation (Nordstrom et al., 2007).

In clinical application, the physical therapist should have theoretical knowledge regarding the best electrical stimulation pattern, which is directly related to the success of FES application (KruegerBeck et al., 2010a). Sometimes a poor choice of electrical stimulation protocol can cause tissue and neuromuscular damage or delay the patient's rehabilitation.

Several FES profiles have been used (KruegerBeck et al., 2010b). The most commonly used FES active pulse periods vary from $100 \mu$ s up to $500 \mu \mathrm{s}$, whereas burst frequencies are adjusted from 20 to $100 \mathrm{~Hz}$ (Bailey et al., 2010; Baptista et al., 2009; Fisekovic and Popovic, 2001; Fujita et al., 1995; Gollee et al., 2004; Jezernik et al., 2004; Langzam et al., 2007; Marsolais and Kobetic, 1988; Marsolais and Kobetic, 1987; Matsunaga et al., 1999; McAndrew et al., 2006; Thrasher et al., 2005, 2006). Burst frequencies lower than $20 \mathrm{~Hz}$ may produce fasciculation during muscular contractions (Petrofsky, 2004), although frequencies over $70 \mathrm{~Hz}$ may cause discomfort during stimulation (Mesin and Merletti, 2008; Packman-Braun, 1988; Rabischong, 1996; Rooney et al., 1992).

The FES magnitude required to evoke artificial functional movements are higher in individuals who have suffered spinal cord injuries than in healthy people (Gollee et al., 2004). Due to the reduction in voluntary muscle contraction, paraplegics have decreased muscle mass, mainly in their fast fibres, and this alteration in the proportions of slow and fast fibres leads to a decrease in force production (Andersen et al., 1999).

Tissue impedance varies depending on the coupling of the electrodes. Dry, intact skin has an impedance of approximately $93.0 \mathrm{k} \Omega / \mathrm{cm}^{2}$ at $60 \mathrm{~Hz}$ (Bronzino, 1992). When surface electrodes (silicon-carbon) are coupled to the skin with electrolyte gel, the impedance reduces to $10.8 \mathrm{k} \Omega / \mathrm{cm}^{2}$ (Bronzino, 1992). FES is delivered through bursts of voltage pulses (Ward and Shkuratova, 2002), and the mean amplitude is related to the energy inside these pulses. Tissue impedance is influenced by many variables, such as the frequency of the electric current, electrochemical processes, temperature, $\mathrm{pH}$, hydration and the viscosity of the biological tissue under analysis (Neves et al., 2009). An inadequate stimulatory profile can result in a high charge density and may create injuries in peripheral nerves (Jezernik and Morari, 2005), as well as in the central nervous system (McCreery et al., 1990). Despite the enormous versatility of electrical parameters in the available stimulators, only the optimal settings will be safe and both physiologically and biomechanically effective.

Using FES to control paralysed limbs, it is essential to design safe stimulatory electrical profiles that will evoke the best muscle response. To this end, we are looking for a safe protocol that will achieve the most efficient contraction while delivering less energy to the patient. Thus, the goal of this study was to investigate the relationship between peak and mean amplitudes of the stimulator output voltage, while causing a knee extension angle change from $90^{\circ}$ to $40^{\circ}$ and to choose the safest and most effective profile among the profiles evaluated in this experimental study.

\section{Methods}

\section{Volunteers}

All volunteers who participated in this study read and signed an informed consent form before the beginning of any procedure. The experimental protocol was approved by the Human Research Ethics Committee. Ten healthy volunteers (HV) without neurological or orthopaedic disorders ( $28.30 \pm 6.58$ yrs) were selected from academic students of Pontifícia Universidade Católica do Paraná (PUCPR), and sixteen spinal cord injured volunteers (SCIV) $(32.06 \pm 9.68 \mathrm{yrs})$ were chosen from Hospital Rehabilitation Centre Ana Carolina Moura Xavier (Curitiba, Paraná, Brazil) to participate in this study. An assessment was conducted in SC to verify the inclusion/exclusion criteria. During the physical examination, power (Higuet scale from 0 to 5 ), reflexivity (Wexler scale from 0 to 5), spasticity (Ashworth modified scale from 0 to 4 ) and the American Spinal Injury Association (ASIA) impairment scale (from A to E) were evaluated. During the tests, the volunteers did not use any drugs that could change their motor condition. Among the volunteers with spinal cord injury, only ten met the criteria for inclusion in this study. Ten SCIVs is reasonable, considering (a) the specificity of the population studied and (b) that the number of subjects reported in the present study includes at least as many SCIVs as did similar experiments found in the literature (Davoodi and Andrews, 2004; Tepavac and Schwirtlich, 1997; Uhlir et al., 2000; Williamson and Andrews, 2000). 


\section{Electrical stimulation parameters}

A custom electrical stimulator (Ariana - 16 channels) (Zagheni, 1998) was calibrated with a two-channel oscilloscope Tektronix ${ }^{\circledR}$ TDS $1002 \mathrm{~B}$ and a $1-\mathrm{k} \Omega$ resistor to simulate skin impedance (Bronzino, 1992). The stimulatory waveform was a monophasic square wave with four FES profiles shown in Table 1 configured with different duty cycles, frequencies, pulse periods and burst periods.

After trichotomy and skin cleaning procedures, two self-adhesive electrodes $(4.5 \times 9.0 \mathrm{~cm})$ were positioned on the knee region (anode) and on the femoral triangle (cathode) to stimulate the quadriceps muscle (Figure 1).

\section{Angular data acquisition}

A custom monoaxial electrogoniometer built with a $10-\mathrm{k} \Omega$ linear potentiometer was placed laterally to the knee to acquire the knee joint angle (Figure 1). All signals and volunteer data were saved into European Data Format (EDF) files. The acquisition system contained a DT300 series Data Translation ${ }^{\mathrm{TM}}$ board working at a $1 \mathrm{kHz}$ sampling rate.

\section{Electrical stimulation protocol and data acquisition}

All FES profiles (Table 1) were applied to each volunteer randomly, one profile per day, over four testing days with a minimal interval of two rest days (Kesar et al., 2008; Marion et al., 2010; Smith et al., 1997; Stock et al., 2010) between the tests to avoid physiological interference between consecutive protocols. The volunteer was positioned on an adapted chair with the hip and knee angles set to $70^{\circ}$ (Matsunaga et al., 1999) and $90^{\circ}$, respectively, as illustrated in Figure 1. The electrogoniometer signal was zeroed at the maximum knee extension (i.e., angle defined as $0^{\circ}$ ). After the zeroing step, the leg was placed at the $90^{\circ}$ initial rest position (as shown in Figure 1). Then, the magnitude of the electrical stimuli was adjusted according to the knee movement range from $90^{\circ}$ to $40^{\circ}$. When the knee joint reached an angle of $40^{\circ}$, the corresponding stimulator output amplitude was determined, and electrical stimulation was ceased.

Table 1. FES profiles chosen for the experimental protocol.

\begin{tabular}{|c|c|c|c|c|c|c|}
\hline \multirow{2}{*}{ Profile } & \multicolumn{3}{|c|}{ Pulse } & \multicolumn{3}{|c|}{ Burst } \\
\hline & On $(\mu s)$ & Off $(\mu s)$ & Frequency (kHz) & On (ms) & Off (ms) & Frequency $(\mathrm{Hz})$ \\
\hline P1 & 100 & 900 & 1 & 3 & 17 & 50 \\
\hline P2 & 100 & 900 & 1 & 3 & 11 & 70 \\
\hline P3 & 200 & 800 & 1 & 3 & 17 & 50 \\
\hline P4 & 200 & 800 & 1 & 3 & 11 & 70 \\
\hline
\end{tabular}

On: active pulse duration; Off: inactive pulse duration; pulse on time: $100 \mu \mathrm{s}, 200 \mu$ s (Jezernik et al., 2004); pulse frequency: $1 \mathrm{kHz}$ (Ward and Robertson, 1998); burst frequency: $50 \mathrm{~Hz}$ and $70 \mathrm{~Hz}$ (Chou et al., 2005).
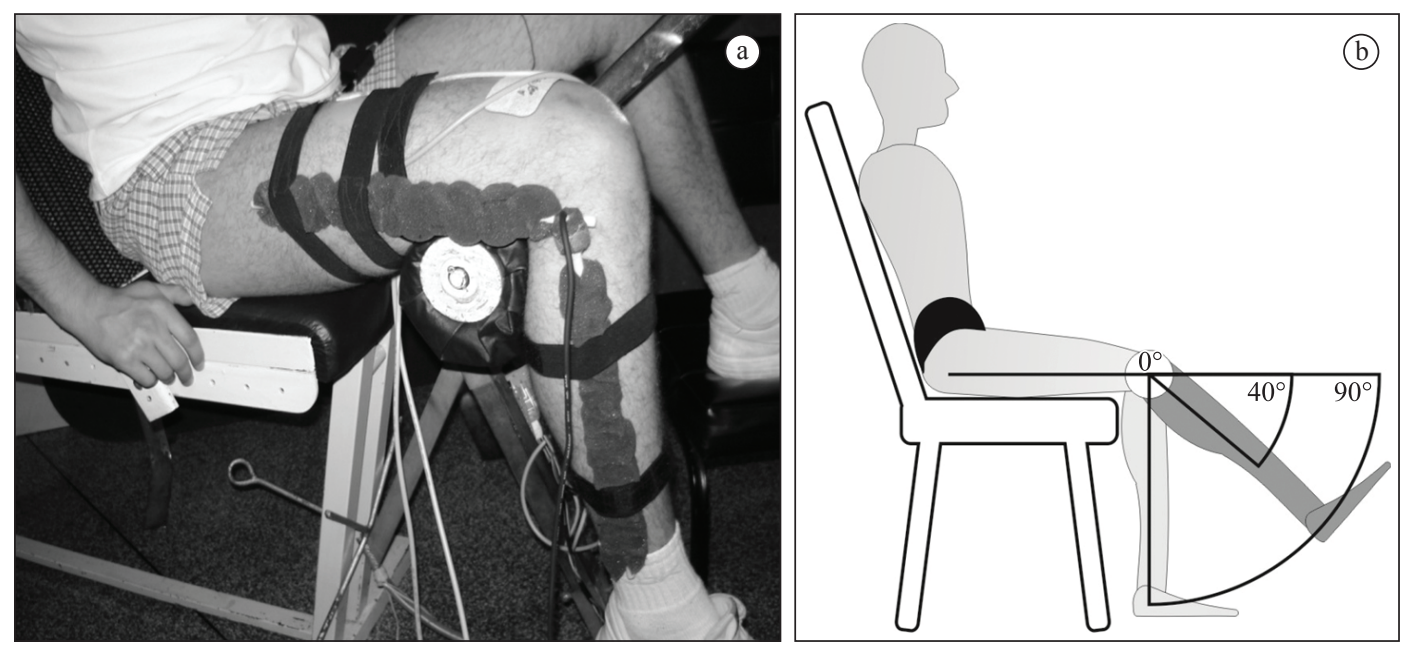

Figure 1. a) Volunteer positioned in the adapted chair. An electrogoniometer was fixed laterally to the knee joint, and FES electrodes were fixed on the skin over the supra-patellar and femoral triangle regions. b) Knee joint angle positions. 


\section{Analysis}

The mean amplitude was calculated by means of Equation 1:

$V_{\text {Mean }}=V_{\text {Peak }}\left(\frac{T_{o n}}{T_{T}} \times \frac{T_{B o n}}{T_{B T}}\right)$

where

- $V_{\text {Mean }}$ is the mean amplitude expressed in volts (V);

- $V_{\text {Peak }}$ is the peak amplitude;

- $T_{o n}$ is the active pulse period;

- $T_{T}$ is the total pulse period;

- $T_{B o n}$ is the active burst period;

- $T_{B T}$ is the total burst period.

The application of the Kolmogorov-Smirnov test showed that the data followed a Gaussian distribution. The software PASW Statistics 18 was used to perform the statistical analysis: (I) One-sample Student's t-tests were applied to compare peak and mean amplitudes for HV and SCIV participants, split by FES profiles; (II) Independent t-tests were applied to compare HV and SCIV groups in terms of peak and mean amplitude split by FES profiles; (III) A one-way analysis of variance (ANOVA) with LSD post-hoc test was applied to data split into HV and SCIV groups to find the profile which resulted in the lowest peak and mean output amplitudes.

\section{Ethical considerations}

This study was performed according to the Declaration of Helsinki and was approved by Pontifícia
Universidade Católica do Paraná's (PUCPR) Human Research Ethics Committee under register n. 2416/08.

\section{Results}

Six SCIVs were excluded from the initial group of volunteers because they either did not tolerate the sensation evoked by the electrical current or because of denervation of motor units. Table 2 presents demographic information for the participants and indicates the motor response parameters reflecting their neuromuscular conditions. Sudden onset of spasticity was not observed during the protocol due to FES-induced inhibition.

One-sample Student's t-tests indicated that peak and mean amplitudes are different $(\mathrm{p}<0.01)$ for both $\mathrm{HV}$ and SCIV groups. Independent t-tests showed that peak and mean amplitudes necessary to stimulate HVs were smaller than those for SCIVs across all FES profiles. Table 3 shows the peak and mean voltage amplitudes applied during FES for healthy and spinal cord injured volunteers in different electrical stimulation profiles. Figures 2 and 3 show post-hoc comparisons of peak and mean voltages, respectively, for different FES profiles in HVs and SCIVs.

\section{Discussion}

The one-sample Student's t-tests demonstrated that peak and mean amplitudes were different $(\mathrm{P}<0.01)$ for both HVs and SCIVs. According to the independent t-test, the peak and mean amplitudes required for raising the leg to $40^{\circ}$ of knee flexion were higher

Table 2. Clinical data of volunteers with spinal cord injuries.

\begin{tabular}{|c|c|c|c|c|c|c|c|c|c|c|c|}
\hline \multirow{2}{*}{ Vol } & \multirow{2}{*}{ Age } & \multicolumn{4}{|c|}{$\begin{array}{c}\text { Spinal cord injury } \\
\end{array}$} & \multirow{2}{*}{$\frac{\text { Sensibility }}{\text { L1-L2 }}$} & \multicolumn{3}{|c|}{ Motor system } & \multicolumn{2}{|c|}{ Deliverance } \\
\hline & & Aetiology & Level & Months & ASIA & & Power & Reflex & Spasticity & $\mathbf{A}$ & NA \\
\hline $\mathrm{A}$ & 25 & Violence & T8 & 24 & $\mathrm{~A}$ & - & 0 & 0 & 0 & & $\mathrm{X}$ \\
\hline $\mathrm{B}$ & 46 & Automobile & $\mathrm{T} 8$ & 31 & A & - & 0 & 2 & 0 & $\mathrm{X}$ & \\
\hline $\mathrm{C}$ & 30 & Violence & T6 & 84 & $\mathrm{~A}$ & - & 0 & 2 & +1 & $\mathrm{X}$ & \\
\hline $\mathrm{D}$ & 28 & Automobile & $\mathrm{T} 12$ & 48 & $\mathrm{~B}$ & + & 0 & 1 & 0 & $\mathrm{X}$ & \\
\hline $\mathrm{E}$ & 29 & Automobile & $\mathrm{T} 12$ & 108 & $\mathrm{C}$ & + & 1 & 3 & 2 & & $X$ \\
\hline $\mathrm{F}^{*}$ & 26 & Violence & T10-11 & 168 & A & - & 0 & 2 & +1 & & $\mathrm{X}$ \\
\hline G & 34 & Automobile & T4-5 & 84 & A & - & 0 & 2 & 1 & & $X$ \\
\hline $\mathrm{H}$ & 24 & Violence & $\mathrm{T} 12$ & 24 & A & - & 0 & 0 & 0 & & $\mathrm{X}$ \\
\hline I & 25 & Automobile & $\mathrm{T} 12$ & 18 & $\mathrm{~A}$ & - & 0 & 0 & 0 & & $\mathrm{X}$ \\
\hline $\mathrm{J}$ & 37 & Diving & $\mathrm{C} 5-6$ & 162 & B & - & 0 & 3 & 1 & $X$ & \\
\hline $\mathrm{K}$ & 19 & Violence & $\mathrm{T} 10$ & 12 & B & + & 0 & 3 & 1 & $\mathrm{X}$ & \\
\hline $\mathrm{L}$ & 48 & Fall & $\mathrm{T} 11$ & 60 & $\mathrm{D}$ & + & 3 & 3 & 2 & & X \\
\hline M & 52 & Other & L4 & 60 & $\mathrm{D}$ & + & 4 & 2 & 0 & & $\mathrm{X}$ \\
\hline $\mathrm{N}$ & 26 & Automobile & C6-7 & 28 & B & + & 0 & 3 & 2 & $X$ & \\
\hline $\mathrm{O}$ & 28 & Automobile & T3 & 60 & A & - & 0 & 0 & 1 & $\mathrm{X}$ & \\
\hline $\mathrm{P}$ & 36 & Other & L1 & 132 & $\mathrm{D}$ & + & 4 & 2 & 0 & & $\mathrm{X}$ \\
\hline
\end{tabular}


Table 3. Peak and mean voltages for healthy volunteers and volunteers with spinal cord injuries.

\begin{tabular}{lccccc}
\hline & & P1 (V) & P2 $(\mathbf{V})$ & P3 (V) & P4 (V) \\
\hline HV & $\mathrm{V}_{\text {peak }}$ & $82.20 \pm 16.73$ & $76.60 \pm 22.16$ & $91.90 \pm 33.23$ & $67.60 \pm 13.97$ \\
& $\mathrm{~V}_{\text {mean }}$ & $1.23 \pm 0.25$ & $1.64 \pm 0.47$ & $2.75 \pm 0.99$ & $2.90 \pm 0.59$ \\
SCIV & $\mathrm{V}_{\text {peak }}$ & $161.40 \pm 36.39$ & $154.60 \pm 41.96$ & $150.80 \pm 49.51$ & $121.80 \pm 53.55$ \\
& $\mathrm{~V}_{\text {mean }}$ & $2.42 \pm 0.54$ & $3.31 \pm 0.89$ & $4.52 \pm 1.48$ & $5.22 \pm 2.29$ \\
\hline
\end{tabular}

$\mathrm{V}_{\text {peak }}:$ Peak amplitude; $\mathrm{V}_{\text {mean }}:$ Mean amplitude.

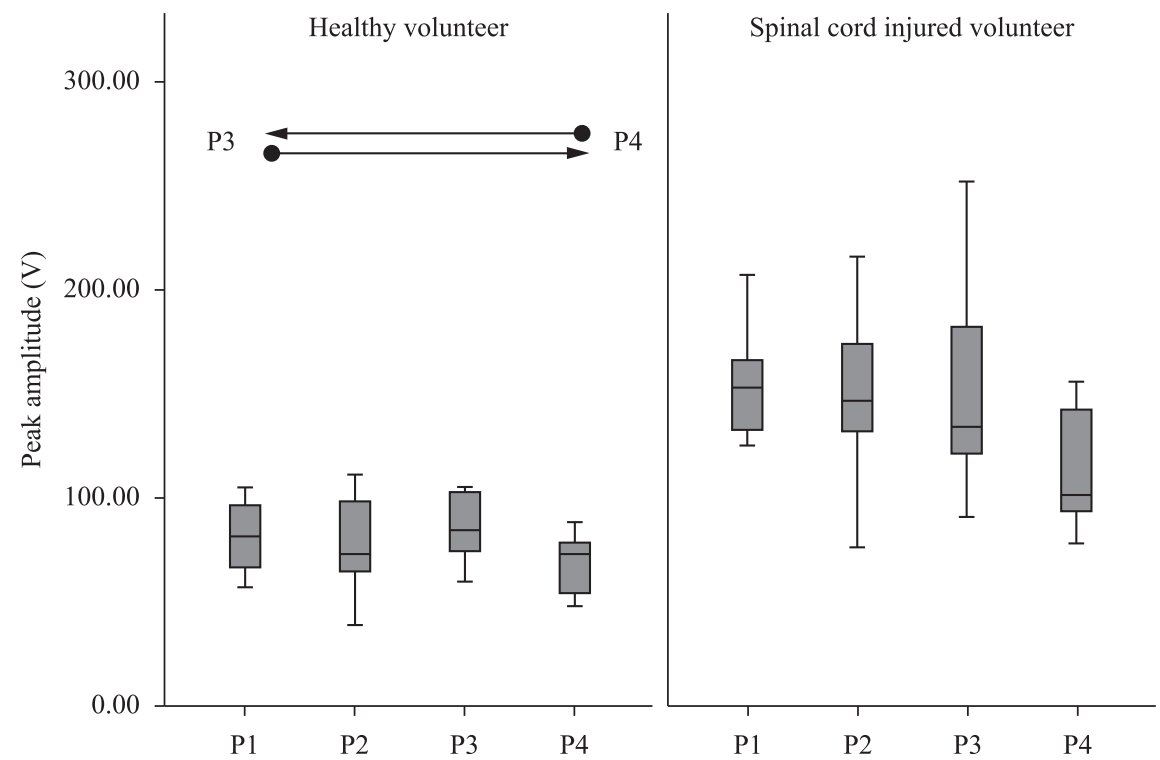

Figure 2. Peak amplitudes required to achieve $40^{\circ}$ of knee flexion in four FES profiles and any statistically significant differences. Open circles: 35, 69 and 72 are outliers; Closed circles: control; Arrows: statistically significant differences $(\mathrm{p} \leq 0.05)$.

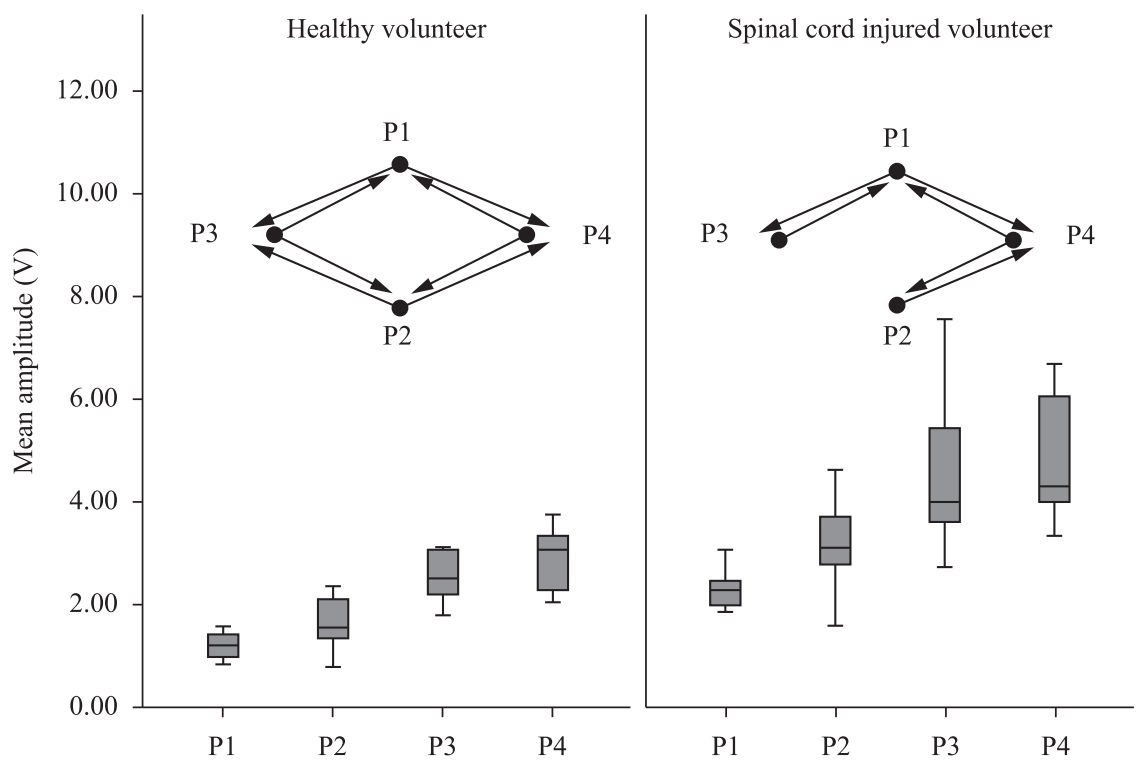

Figure 3. Mean amplitudes required to achieve $40^{\circ}$ of knee flexion in four FES profiles and the statistical significance of the differences. Open circles: 35, 69 and 72 outliers; Closed circles: control; Arrows: statistically significant differences $(\mathrm{p} \leq 0.05)$.

in SCIVs than in HVs (Figures 2 and 3), which is consistent with the findings of Gollee et al. (2004). This result is most likely related to muscle atrophy in SCIVs (Andersen et al., 1999; Kern et al., 2010a) and the consequent difference in $\mathrm{Ca}^{++}$activation of cross bridges in sarcomere cells (Gobbo et al., 2006). FES may have triggered a muscle cell recovery process (Thrasher et al., 2006) and may also lead to 
hypertrophy (Kern et al., 2010b); thus, the stimulation amplitude required to achieve a knee flexion angle of $40^{\circ}$ may decrease during the recovery process of neuromuscular tissue.

Regarding peak amplitude, Figure 2 shows that $\mathrm{P} 4$ required the weakest amplitudes to achieve $40^{\circ}$ of knee flexion for both HVs and SCIVs. The low peak amplitude in P4 is due to the greater pulse duty cycle (on time and its period ratio: $200 \mu \mathrm{s} / 1000 \mu \mathrm{s}$ ) and also to the $22 \%$ burst duty cycle ( $3 \mathrm{~ms} / 14 \mathrm{~ms}$, i.e., the active and total burst period ratio), which allow more energy to be released to the tissue compared to the other FES profiles investigated (Table 1). This finding may explain the fact that for HVs, there was only a statistically significant difference $(p<0.05)$ between P3 and P4 FES profiles. Laufer and Elboim (2008) found that a $20 \%$ burst duty cycle ( $4 \mathrm{~ms} / 20 \mathrm{~ms}$ ) was better than $50 \%$ burst duty cycle $(10 \mathrm{~ms} / 20 \mathrm{~ms})$ in minimising muscle fatigue while evoking strong muscle contractions. The results of Laufer and Elboim (2008) were different from those obtained in the present study, in which the profiles with lower burst duty cycles (P1 and $\mathrm{P} 3,15 \%)$ required different mean amplitudes to achieve $40^{\circ}$ of knee flexion. P1 required a weaker mean amplitude, even with the same burst duty cycle as that of P3. In fact, the FES profiles with low pulse duty cycles, as well as low burst duty cycles, were better than the FES profiles with only low burst duty cycles.

According to the results shown in Figure 3, P1 is the profile that required the weakest mean values of electrical stimulation to achieve $40^{\circ}$ of knee flexion for both HVs and SCIVs; there was also no significant difference at the $\mathrm{p}<0.05$ level between the active pulse ratios for P1 and P2 (100 $\mu \mathrm{s} / 1000 \mu \mathrm{s})$. Considering the different trends between peak and mean amplitudes, $\mathrm{P} 4$ is the profile that required the highest mean amplitude and the lowest peak amplitude to achieve $40^{\circ}$ of knee flexion for both HVs and SCIVs. McLoda and Carmak (2000) studied different burst duty cycles $(10,30,50,70$ and $90 \%)$ and found that $10 \%$ was the optimum for eliciting the strongest muscle contraction. In the present study, the mean amplitude necessary to elicit $40^{\circ}$ of knee flexion was minimised by the FES profile with a lower pulse duty cycle and lower burst duty cycle.

According to Shannon (1992), safety limits for electrical stimulation rely on several parameters, including waveform shape, electrode sizes and charge densities. These limits must be found for patient safety during FES. The P4 profile applied higher mean currents (Vanderthommen and Duchateau, 2007) to volunteers and, theoretically, may have produced greater increases in skin temperature; greater increases in skin temperature may cause lesions, such as burns (Popovic et al., 2001), especially in individuals with spinal cord injuries, who usually are less sensitive to nociceptive stimuli (Maynard et al., 1997). Because the P1 and P2 FES profiles did not show significant differences, choosing one of them would result in smaller applied mean currents, but P2, with a burst frequency of $70 \mathrm{~Hz}$, may cause sensorial discomfort in patients with augmented nociceptive sensitivity (Packman-Braun, 1988; Rabischong, 1996; Rooney et al., 1992).

Due to the current research design, our study was limited by the inability to control certain variables, such as the skin-electrode interface, involuntary contraction (healthy subjects) due to FES and possible diffusion to other muscles (spill-over effect). However, the results showed that the stimulating profiles studied effectively generated functional muscular contractions (in our protocol, knee flexion) and can be generalised unless more detailed studies obtain different results.

In FES applications, peak and mean amplitudes delivered by electrical stimulation exhibited different values and responses. The peak and mean amplitudes required for raising the leg and changing the knee flexion angle from $90^{\circ}$ to $40^{\circ}$ were higher for SCIVs than for HVs. For both SCIVs and HVs, the FES profile with duty cycles of $200 \mu \mathrm{s} / 1000 \mu \mathrm{s}$ and $3 \mathrm{~ms} / 14 \mathrm{~ms}$, for pulse and burst, respectively, required smaller peak amplitudes to achieve $40^{\circ}$ of knee flexion. The smallest mean amplitudes were obtained for profile P1 with duty cycles of $100 \mu \mathrm{s} / 1000 \mu \mathrm{s}$ and $3 \mathrm{~ms} / 20 \mathrm{~ms}$ for pulse and burst, respectively. Therefore, P1 seems to be the most suitable FES profile for HVs and SCIVs because it presented the smallest mean amplitudes and, consequently, presents smaller hypothetical increases in skin temperature. Moreover, it can be postulated that the P1 burst frequency $(50 \mathrm{~Hz})$ might have caused less nociceptive sensation (low frequencies) compared to other FES profiles used in this study. Healthcare professionals involved with spinal cord injury rehabilitation may use this information to plan treatments using stimulation parameters that promote functional movements effectively and safely with regard to the energy transferred by the stimulating current.

\section{Acknowledgements}

We would like to thank CNPq, CAPES and SETIPR for providing scholarships and financial support.

\section{References}

Andersen JL, Gruschy-Knudsen T, Sandri C, Larsson L, Schiaffino S. Bed rest increases the amount of mismatched 
fibres in human skeletal muscle. Journal of Applied Physiology. 1999; 86(2):455-60. PMid:9931176.

Bailey SN, Hardin EC, Kobetic R, Boggs LM, Pinault G, Triolo RJ. Neurotherapeutic and neuroprosthetic effects of implanted functional electrical stimulation for ambulation after incomplete spinal cord injury. Journal of Rehabilitation Research \& Development. 2010; 47(1):7-16. http://dx.doi. org/10.1682/JRRD.2009.03.0034

Baptista RR, Scheeren EM, Macintosh BR, Vaz MA. Lowfrequency fatigue at maximal and submaximal muscle contractions. Brazilian Journal of Medical and Biological Research. 2009; 42:380-5. PMid:19330267. http://dx.doi. org/10.1590/S0100-879X2009000400011

Bohannon RW, Smith M. Interrater reliability of a Modified Ashworth Scale of muscle spasticity. Physical Therapy. 1987 Feb; 67(2):206-7. PMid:3809245.

Bronzino JD. Management of medical technology: a primer for clinical engineers. Boston: Butterworth-Heinemann; 1992. PMid:1596745.

Chou LW, Ding J, Wexler AS, Binder-Macleod SA. Predicting optimal electrical stimulation for repetitive human muscle activation. Journal of Electromyography and Kinesiology. 2005; 15(3):300-9. PMid:15763677. http:// dx.doi.org/10.1016/j.jelekin.2004.10.002

Cipriano JJ. Photographic manual of regional orthopaedic and neurological tests. 4th ed. Atlanta: Lippincott Williams \& Wilkins; 2003.

Davoodi R, Andrews BJ. Fuzzy logic control of FES rowing exercise in paraplegia. IEEE Transactions on Biomedical Engineering. 2004 Mar; 51(3):541-3. PMid:15000386. http://dx.doi.org/10.1109/TBME.2003.821043

Enoka RM, Duchateau J. Muscle fatigue: what, why and how it influences muscle function. The Journal of Physiology. 2008; 586(1):11-23. PMid:17702815 PMCid:2375565. http://dx.doi.org/10.1113/ jphysiol.2007.139477

Fisekovic N, Popovic DB. New controller for functional electrical stimulation systems. Medical Engineering and Physics. 2001; 23(6):391-9. http://dx.doi.org/10.1016/ S1350-4533(01)00069-8

Fujita K, Handa Y, Hoshimiya N, Ichie M. Stimulus adjustment protocol for FES-induced standing in paraplegiausing percutaneous intramuscular electrodes. IEEE Transactions on Rehabilitation Engineering. 1995; 3(4):360-6. http://dx.doi.org/10.1109/86.481976

Gobbo M, Cè E, Diemont B, Esposito F, Orizio C. Torque and surface mechanomyogram parallel reduction during fatiguing stimulation in human muscles. European Journal of Applied Physiology. 2006; 97(1):9-15. PMid:16477444. http://dx.doi.org/10.1007/s00421-006-0134-8

Gollee H, Hunt KJ, Wood DE. New results in feedback control of unsupported standing in paraplegia. IEEE Transactions on Neural Systems and Rehabilitation
Engineering. 2004; 12(1):73-80. PMid:15068190. http:// dx.doi.org/10.1109/TNSRE.2003.822765

Jezernik S, Morari M. Energy-optimal electrical excitation of nerve fibres. IEEE Transactions on Biomedical Engineering. 2005; 52(4):740-3. PMid:15825876. http:// dx.doi.org/10.1109/TBME.2005.844050

Jezernik S, Wassink RGV, Keller T. Sliding mode closedloop control of FES: controlling the shank movement. IEEE Transactions on Biomedical Engineering. 2004; 51(2):263-72. PMid:14765699. http://dx.doi.org/10.1109/ TBME.2003.820393

Kern H, Carraro U, Adami N, Biral D, Hofer C, Forstner C, Modlin M, Vogelauer M, Pond A, Boncompagni S. Home-based functional electrical stimulation rescues permanently denervated muscles in paraplegic patients with complete lower motor neuron lesion. Neurorehabil Neural Repair. 2010a May; 24(8):709-21. PMid:20460493. http:// dx.doi.org/10.1177/1545968310366129

Kern H, Stramare R, Martino L, Gargiulo P, Carraro U. Permanent LMN denervation of human skeletal muscle and recovery by hb FES: management and monitoring. European Journal Translational Myology. 2010b; 20(3):91-104.

Kesar T, Chou LW, Binder-Macleod SA. Effects of stimulation frequency versus pulse duration modulation on muscle fatigue. Journal of Electromyography and Kinesiology. 2008 Aug; 18(4):662-71. PMid:17317219 PMCid:2562565. http:// dx.doi.org/10.1016/j.jelekin.2007.01.001

Kesar TM, Perumal R, Jancosko A, Reisman DS, Rudolph KS, Higginson JS, Binder-Macleod SA. Novel patterns of functional electrical stimulation have an immediate effect on dorsiflexor muscle function during gait for people poststroke. Physical Therapy. 2010; 90(1):55-66. PMid:19926681 PMCid:2802826. http://dx.doi.org/10.2522/ptj.20090140

Krueger-Beck E, Scheeren E, Nogueira-Neto GN, Button VLdSN, Nohama P. Optimal FES parameters based on mechanomyographic efficiency index. In: Annual International Conference of the IEEE EMBC: Proceedings of the Annual International Conference of the IEEE Engineering in Medicine and Biology Society; 2010 Aug 31-Sept 4; Buenos Aires, Argentina. Buenos Aires: IEEE; 2010a. p. 1378-81. PMid:21096336.

Krueger-Beck E, Scheeren EM, Nogueira-Neto GN, Button VLdSN, Nohama P. Efeitos da estimulação elétrica funcional no controle neuromuscular artificial. Revista Neurociências. 2010b; 1-11. In Press.

Langzam E, Nemirovsky Y, Isakov E, Mizrahi J. Muscle enhancement using closed-loop electrical stimulation: Volitional versus induced torque. Journal of Electromyography and Kinesiology. 2007; 17(3):275-84. PMid:16690326. http:// dx.doi.org/10.1016/j.jelekin.2006.03.001

Laufer Y, Elboim M. Effect of burst frequency and duration of kilohertz-frequency alternating currents and of low-frequency pulsed currents on strength of contraction, muscle fatigue, and perceived discomfort. Physical Therapy. 2008; 88(10):1167. PMid:18703676. http://dx.doi.org/10.2522/ptj.20080001 
Marion MS, Wexler AS, Hull ML. Predicting fatigue during electrically stimulated non-isometric contractions. Muscle \& Nerve. 2010; 41(6):857-67. PMid:20229581. http://dx.doi. org/10.1002/mus.21603

Marsolais EB, Kobetic R. Development of a practical electrical stimulation system for restoring gait in the paralyzed patient. Clinical Orthopaedics and Related Research. 1988; 233:64-74. PMid:3261221.

Marsolais EB, Kobetic R. Functional electrical stimulation for walking in paraplegia. Journal of Bone and Joint Surgery. 1987; 69(5):728-33. PMid:3496340.

Matsunaga T, Shimada Y, Sato K. Muscle fatigue from intermittent stimulation with low and high frequency electrical pulses. Archives of Physical Medicine and Rehabilitation. 1999; 80(1):48-53. http://dx.doi.org/10.1016/ S0003-9993(99)90306-4

Maynard FM, Bracken MB, Creasey G, Ditunno JF, Donovan WH, Ducker TB, Garber SL, Marino RJ, Stover $\mathrm{SL}$, Tator $\mathrm{CH}$. International standards for neurological and functional classification of spinal cord injury. Spinal Cord. 1997; 35(5):266-74. PMid:9160449. http://dx.doi. org/10.1038/sj.sc.3100432

McAndrew DJ, Rosser NAD, Brown JMM. Mechanomyographic measures of muscle contractile properties are influenced by the duration of the stimulatory pulse. Journal of Applied Research. 2006; 6(1):142-52.

McCreery DB, Agnew WF, Yuen TGH, Bullara L. Charge density and charge per phase as cofactors in neural injury induced by electrical stimulation. IEEE Transactions on Biomedical Engineering. 1990; 37(10):996-1001. PMid:2249872. http://dx.doi.org/10.1109/10.102812

McLoda TA, Carmack JA. Optimal burst duration during a facilitated quadriceps femoris contraction. Journal of Athletic Training. 2000; 35(2):145-50. PMid:16558623 PMCid:1323410.

Mesin L, Merletti R. Distribution of electrical stimulation current in a planar multilayer anisotropic tissue. IEEE Transactions on Biomedical Engineering. 2008; 55(2):66070. PMid: 18270002 . http://dx.doi.org/10.1109/ TBME.2007.902248

Neves EB, Pino AV, Souza MN. Comparison of two bioimpedance spectroscopy techniques in the assessment of body fluid volumes. In: Annual International Conference of the IEEE EMBC: Proceedings of the 31th Annual International Conference of the IEEE Engineering in Medicine and Biology Society; 2009; Minneapolis, Minnesota. Minneapolis: IEEE; 2009. p. 853-6. PMid:19963476.

Nordstrom MA, Gorman RB, Laouris Y, Spielmann JM, Stuart DG. Does motoneuron adaptation contribute to muscle fatigue? Muscle \& Nerve. 2007; 35(2):135-58. PMid:17195169. http://dx.doi.org/10.1002/mus.20712

Packman-Braun R. Relationship between functional electrical stimulation duty cycle and fatigue in wrist extensor muscles of patients with hemiparesis. Physical Therapy. 1988; 68(1):51-6. PMid:3257300.

Petrofsky JS. Electrical stimulation: neurophysiological basis and application. Basic and Applied Myology. 2004; 14(4):205-13.

Popovic MR, Curt A, Keller T, Dietz V. Functional electrical stimulation for grasping and walking: indications and limitations. Spinal Cord. 2001; 39(8):403-12. PMid:11512070. http://dx.doi.org/10.1038/sj.sc.3101191

Rabischong E. Surface action potentials related to torque output in paraplegics' electrically stimulated quadriceps muscle. Medical Engineering \& Physics. 1996; 18(7):538-47. http://dx.doi.org/10.1016/1350-4533(96)00001-X

Rooney JG, Currier DP, Nitz AJ. Effect of variation in the burst and carrier frequency modes of neuromuscular electrical stimulation on pain perception of healthy subjects. Physical Therapy. 1992; 72(11):800-6. PMid:1409877.

Shannon RV. A model of safe levels for electrical stimulation. IEEE Transactions on Biomedical Engineering. 1992; 39(4):424-6. PMid:1592409. http:// dx.doi.org/10.1109/10.126616

Smith DB, Housh, Terry J., Stout JR, Johnson GO, Evetovich TK, Ebersole KT. Mechanomyographic responses to maximal eccentric isokinetic muscle actions. Journal of Applied Physiology. 1997; 82(3):1003-7. PMid:9074994.

Stock MS, Beck TW, DeFreitas JM, Dillon MA. Linearity and reliability of the mechanomyographic amplitude versus dynamic constant external resistance relationships for the biceps brachii. Physiological Measurement. 2010; 31:1487-98. PMid:20871133. http://dx.doi.org/10.1088/09673334/31/11/006

Tepavac D, Schwirtlich L. Detection and prediction of FES-induced fatigue. Journal of Electromyography and Kinesiology. 1997; 7(1):39-50. http://dx.doi.org/10.1016/ S1050-6411(96)00008-9

Thrasher A, Graham GM, Popovic MR. Reducing muscle fatigue due to functional electrical stimulation using random modulation of stimulation parameters. Artificial Organs. 2005; 29(6):453-8. PMid:15926981. http://dx.doi. org/10.1111/j.1525-1594.2005.29076.x

Thrasher TA, Flett HM, Popovic MR. Gait training regimen for incomplete spinal cord injury using functional electrical stimulation. Spinal Cord. 2006; 44(6):357-61. PMid:16249784. http://dx.doi.org/10.1038/sj.sc.3101864

Uhlir JP, Triolo RJ, Kobetic R. The use of selective electrical stimulation of the quadriceps to improve standing function in paraplegia. IEEE Transactions on Rehabilitation Engineering. 2000; 8(4):514-22. PMid:11204043. http:// dx.doi.org/10.1109/86.895955

Vanderthommen M, Duchateau J. Electrical stimulation as a modality to improve performance of the neuromuscular system. Exercise and Sport Sciences Reviews. 2007; 35(4):180-5. PMid:17921786. http://dx.doi. org/10.1097/jes.0b013e318156e785 
Ward AR, Robertson VJ. Variation in torque production with frequency using medium frequency alternating current* 1,*2. Archives of Physical Medicine and Rehabilitation. 1998; 79(11):1399-404. http://dx.doi. org/10.1016/S0003-9993(98)90234-9

Ward AR, Shkuratova N. Russian electrical stimulation: the early experiments. Physical Therapy. 2002; 82(10):1019. PMid:12350217.

Williamson R, Andrews BJ. Sensor systems for lower limb functional electircal stimulation (FES) control. Medical
Engineering \& Physics. 2000; 22(5):313-25. http://dx.doi. org/10.1016/S1350-4533(00)00038-2

Yu NY, Chang SH. The Characterization of contractile and myoelectric activities in paralyzed tibialis anterior post electrically elicited muscle fatigue. Artificial Organs. 2010; 34(4):E117-E21. PMid:20420602. http:// dx.doi.org/10.1111/j.1525-1594.2009.00956.x

Zagheni AL. Sistema de NMES multicanal controlado por computador para aplicações em locomoção artificial [dissertação]. Curitiba: Universidade Tecnológica Federal do Paraná; 1998.

\footnotetext{
Authors

Eddy Krueger*, Percy Nohama

Programa de Pós-graduação em Engenharia Elétrica e Informática Industrial - CPGEI, Laboratório de Engenharia de Reabilitação, Universidade Tecnológica Federal do Paraná - UTFPR, Av. Sete de Setembro, 3165, CEP 80230-901, Curitiba, PR, Brasil.
}

\section{Eduardo Mendonça Scheeren}

Programa de Pós-graduação em Tecnologia em Saúde - PPGTS, Escola de Saúde e Biociências e Escola Politécnica, Pontifícia Universidade Católica do Paraná - PUCPR, CEP 80250-901, Curitiba, PR, Brasil.

\section{Guilherme Nunes Nogueira-Neto, Vera Lúcia da Silveira Nantes Button}

Departamento de Engenharia Biomédica - DEB, Faculdade de Engenharia Elétrica e Computação - FEEC, Centro de Engenharia Biomédica - CEB, Universidade Estadual de Campinas - UNICAMP, Cidade Universitária “Zeferino Vaz", CEP 13084-971, Campinas, SP, Brasil.

\section{Eduardo Borba Neves}

Programa de Pós-graduação em Engenharia Biomédica, Departamento Acadêmico de Eletrônica, Universidade Tecnológica Federal do Paraná - UTFPR, Rebouças, CEP 80230-901, Curitiba, PR, Brasil. 